\title{
Enoxaparin-associated Spontaneous Breast Haematoma in Elderly with Chronic Kidney Disease: A Case Report
}

\author{
Kronik Böbrek Hastalığı olan Yaşlı Bir Hastada Enoksaparine bağlı elişen Spontan Meme Hematomu: \\ Olgu Sunumu
}

Siti Salwa Shokri ${ }^{1}$, Firdaus Hayati ${ }^{2}$, Aishath Azna $\mathrm{Ali}^{1}$, Suraya Othman ${ }^{3}$, Nor Faezan Abdul Rashid ${ }^{3}$ Shahrun Niza Abdullah Suhaimi ${ }^{1}$

${ }^{1}$ Department of Surgery, Faculty of Medicine, Universiti Kebangsaan, Malaysia

${ }^{2}$ Department of Surgery, Faculty of Medicine and Health Sciences, Universiti Malaysia Sabah, Malaysia

${ }^{3}$ Department of General Surgery, Surgical Sciences Cluster, Faculty of Medicine, Universiti Teknologi MARA, Malaysia

\begin{abstract}
Thomboembolic events are relatively common among elderly with restricted mobility. These adversities include deep vein thrombosis and pulmonary embolism that require anticoagulants as the mainstay of treatment. The elderly are not only at higher risk of thromboembolism, but also have a higher haemorrhagic complication especially among chronic kidney disease. Physicians should be cautious of haematoma formation if they present with sudden onset of painful breast swelling. We describe a rare case of an elderly with underlying chronic kidney disease who developed spontaneous right breast haematoma after taking low molecular weight heparin for her recently diagnosed pulmonary embolism.
\end{abstract}

Key Words: Breast haematoma, enoxaparin, spontaneous, elderly

Received: 03.14.2017

Accepted: 06.05.2017
ÖZET

Thomboembolik olaylar, hareketliliğin sınırlı olduğu yaşlılarda nispeten sıktır. Bu olumsuzluklara, derin ven trombozu ve pulmoner emboli gibi tedavinin başlangıcında pıhtılaşma önleyici ilaçların gerekli olduğu hastalıklar dahildir. Yaşlılarda, sadece tromboembolizm riski yüksek değildir, aynı zamanda özellikle kronik böbrek hastalığı açısından yüksek hemorajik komplikasyonlara da sahiptirler. Hekimler, ani başlangıçlı meme büyümesi ile karşı karşıya kaldıklarında hematom oluşumuna karşı dikkatli olmalılardır. Bu olgu sunumunda; altta kronik böbrek hastalığı yatan yaşlı bir hastada yakın zamanda tanısı konmuş olan pulmoner emboli tedavisi için düşük moleküler ağırlıklı heparin kullandıktan sonra gelişen spontan sağ meme hematomunu sunuyoruz.

Anahtar Sözcükler: Meme hematomu, enoksaparin, spontan, yaşlı

Geliş Tarihi: $\quad$ 14.03.2017

Kabul Tarihi: 05.06.2017

\footnotetext{
INTRODUCTION

Elderly are not only prone to the risk of thromboembolic event, but also have a higher haemorrhagic complication. Their physical and physiological changes have led to predilection of venous thrombosis following Virchow's triad. Anticoagulants are one of the most frequently prescribed treatments for them. However, those drugs are without their own side effects and complications specifically among chronic kidney disease (CKD) and liver failure patients. Easy susceptibility to trauma, neglection towards drug interaction, forgetfulness to drug administration or monitoring will induce the difficulty in managing them. Most feared complication among anticoagulant user is haemorrhagic event that can be life threatening.
}

Low molecular weight heparin (LMWH) has been shown to be safe and effective for the treatment of venous thromboembolism (1-4). It has become the treatment of choice for inpatient as well as for outpatient setting. It is needless for laboratory monitoring, easy to administer, and less interactions with other medications or food $(1,5)$. It is metabolized in the liver and kidney. It can accumulate in CKD patient and potential to produce serious haemorrhage. Major haemorrhagic consequences have been reported before such as haematoma of the retroperitoneum, lower extremities and rectus sheath $(1,2,5,6)$. We report a case of an elderly lady with CKD who suffered from spontaneous right breast haematoma after taking low molecular weight heparin for her recently diagnosed pulmonary embolism. 


\section{CASE REPORT}

An 87-year-old lady, presented with sudden onset of painful right breast swelling, which was progressively increasing in size. She denied any history of trauma prior to the event. She was recently diagnosed with pulmonary embolism and was discharged home with injection enoxaparin. She has underlying diabetes mellitus, hypertension and stage III chronic kidney disease (CKD) with baseline creatinine of 114 umol/L. However, she denied haematological or liver disorder. Apart from her antihypertensive and oral hypoglycaemic medications, she was not on oral anticoagulation or antiplatelet.

Upon presentation, she was pale and haemodynamically unstable, but responded to fluid resuscitation. Her right breast was triple the size of her left breast, measuring $20 \times 20 \mathrm{~cm}$ in size (Figure 1). The remainder of the clinical examination was unremarkable. Initial haemoglobin $(\mathrm{Hb})$ level was $5.6 \mathrm{~g} / \mathrm{dL}$, prothrombin time (PT) 18.8, international normalized ratio (INR) 1.62 and activated partial thromboplastin time 47.9. She developed acute on CKD with serum creatinine of $311.4 \mathrm{umol} / \mathrm{L}$ and blood urea of $30.0 \mathrm{mmol} / \mathrm{L}$. Breast ultrasonography revealed a large anechoeic mass occupying the whole right breast with no doppler signal within (Figure 2 and 3). Due to extensive collection, the anterior chest wall muscles were not visualised. The features were most likely to represent a breast haematoma. She was managed conservatively and the enoxaparin was discontinued. Four units of fresh frozen plasma and two units of packed red blood cells were transfused. In view of intractable pain from the huge and tense breast, bedside aspiration of the haematoma was performed and resulted with aspiration of $100 \mathrm{~mL}$ of haemoserous fluid. She remained stable with $\mathrm{Hb}$ post transfusion of $9.6 \mathrm{~g} / \mathrm{dL}$ and INR 1.2. Her right breast slowly recovered and she was then discharged home well after ten days of hospital admission.

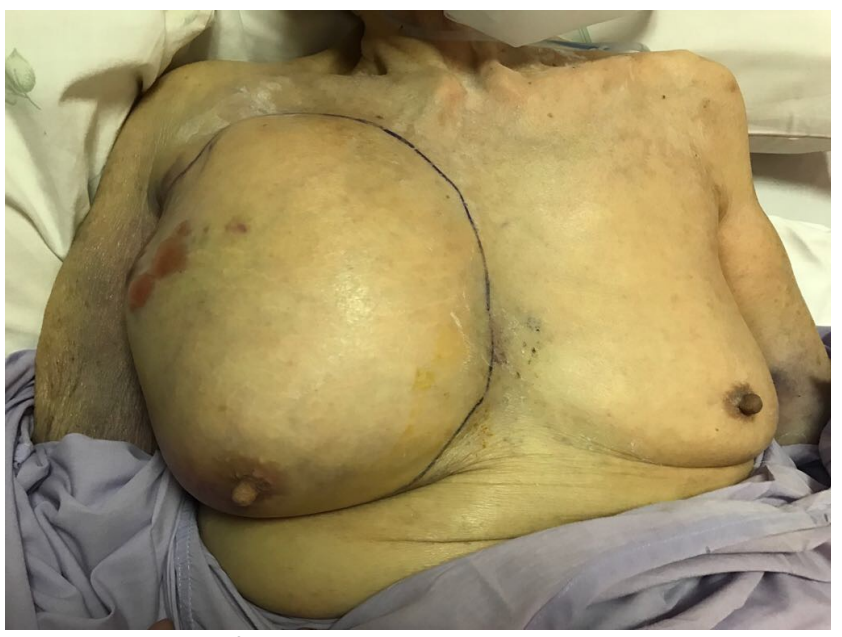

Figure 1: Huge, painful right breast $20 \times 20 \mathrm{~cm}$ in size

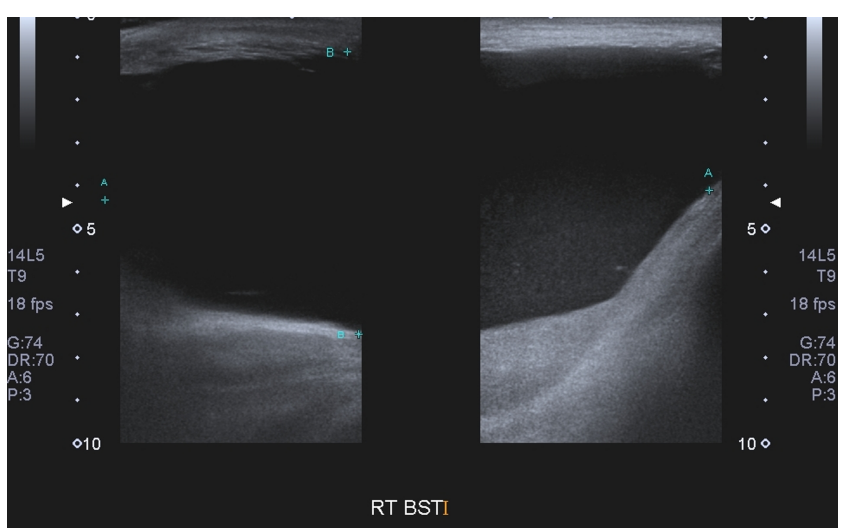

Figure 2: Large anechoeic mass occupying the whole right breast

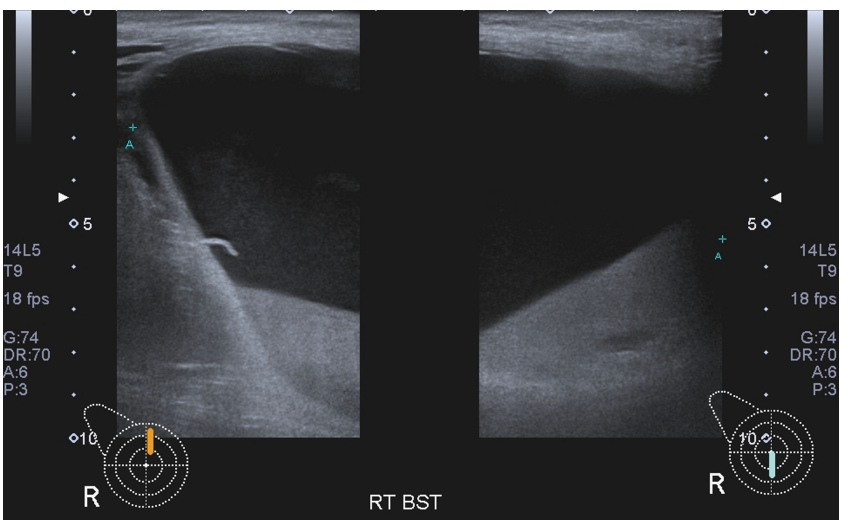

Figure 3: Large anechoeic mass in the whole right breast at upper and lower pole of right breast

\section{DISCUSSION}

Breast hematoma happens as a result of extravasation of the mammary parenchyma. It typically occurs secondary to an insult namely biopsy, surgery, or trauma. Spontaneous breast hematoma is a rare entity. It tends to happen in those with haematologic disorders and coagulopathy especially among anticoagulant consumer. Mostly they will deny history of trauma that makes it distinctive. There were reported cases that have linked spontaneous breast hematoma with warfarin and bleeding disorders $(7,8)$. Up to date, this is the first case of spontaneous breast haematoma reported in association with LMWH.

Enoxaparin is widely used to treat thromboembolic disorders other than warfarin. Advantages of LMWH include it will reduce the need for routine laboratory monitoring, better bioavailability, predictable anticoagulant dose response, can be given daily or twice-daily via subcutaneous route with potential for patient self-injection, and served according to body weight $(3,4)$. Documented risk factors for haematoma occurrence are those with advanced age, concurrent medications such as warfarin and aspirin, presence of thrombocytopaenia and impaired renal function $(1,2,5)$.

Our patient is an elderly lady who was started on enoxaparin therapy after being diagnosed with pulmonary embolism. She presented two weeks later with unprovoked right breast swelling, which was tensed causing unbearable pain. In general, it is a therapeutic challenge to properly manage the elderly once they are on anticoagulants. The benefits must be out weighted the risks and complications. In order to reduce the risk of bleeding and maximise the safety of these group of patients, the renal function should be assessed properly before prescribing. Renal function decreases gradually with age in addition to other medical illnesses, hence affecting the creatinine clearance. For this reason, LMWH can accumulate in patients with impaired renal function thus increases the bleeding risk $(3,4)$. With her advanced age and impaired renal function, we believed CKD itself has triggered the haemorrhage and facilitated the haematoma formation.

Management of spontaneous breast haematoma ranges from simple conservative to complex surgical intervention. It is usually supportive by giving hydration, analgesia, withdrawal of the anticoagulant and correction of the coagulopathy. Occasionally, ultrasound-guided drainage is needed to reduce the size of the swelling. In cases of failed conservative treatment either unresolved swelling or infected hematoma, patient can be subjected for an emergency exploration and evacuation of the haematoma under general anaesthesia. Our patient had received blood transfusion in view of anaemia and undergone bedside aspiration of the haematoma to release the pain-induced tension of the right breast. She was managed conservatively without the need for further invasive intervention.

It is important to acknowledge that breast hematoma may hinder appearance of breast carcinoma. Hematoma secondary to bleeding intracystic tumour can be part of the differential diagnoses. Huge collection as in our case may hide the sonographic evidence of malignancy, as the depth of ultrasound wavelength will be obstructed. The role of mammogram in this case also is undeniably limited unless in a small swelling. Beside using computed tomography to evaluate the hematoma expansion, it can be utilized to rule out localized or distant breast carcinoma (7). 

CONCLUSION

Treating elderly with anticoagulant requires extra considerations especially among CKD patients. It is important to ensure correct dosage following patient's creatinine clearance and compliance towards the medications. If they presented with sudden onset of painful breast swelling, physicians should be aware and acknowledged regarding this rare entity of breast hematoma.

\section{Conflict of interest}

The authors declared no conflict of interest.

\section{REFERENCES}

1. Daggett JR, Chung $\mathrm{S}$, Smith PD. Bilateral spontaneous, simultaneous lower extremity hematomas in a patient on dalteparin. International Journal of Surgery Case Reports. 2013;4:1080-3
2. Besir FH, Gul M, Omek T, Ozer T, Ucan B, Kart L. Enoxaparinassociated giant retroperitoneal hematoma in pulmonary embolism treatment. North American Journal of Medical Sciences. 2011;3:524-6

3. Leri F, Voyce SJ, Scialla S, Glavich W, Dzielak E, Smego RA Jr et al. Enoxaparin dosing in the elderly using adjusted body weight. J Thromb Thrombolysis. 2009;28:348-53

4. Robert-Ebadi $\mathrm{H}, \mathrm{Gal}$ GL, Righini $\mathrm{M}$. Use of anticoagulants in elderly patients: practical recommendations. Clinical Interventions in Aging. 2009;4:165-77

5. Kayrak M, Bacaksiz A, Yazici $M$. Is enoxaparin injection from abdominal wall safe in elderly people? A fatal case of rectus sheath hematoma. Canadian Family Physician. 2008;54:1246-8

6. Sullivan LEJ, Wortham DC, Litton KM. Rectus sheath hematoma with low molecular weight heparin administration: a case series. BMC Reasearch Notes. 2014;7:586

7. Kaya $Y$, Kurt AB, Canakci E, Günaydın ZY, Bektaş O, Öztürk H. Spontaneous breast hematoma associated with warfarin. Middle Black Sea Journal of Health Sciences. 2015;1:22-4

8. Kanegusuku MS, Rodrigues $D$, Urban $L A B D$, Romanus $A B$, Pimenta $\mathrm{RP}$, Asis MGD et al. Recurrent spontaneous breast hematoma: Report of a case and review of literature. Rev Hosp Clin Fac Med S Paulo. 2001;56:179-82 